\title{
Use of fractal dimensions to quantify coral shape
}

\author{
B. Martin-Garin · B. Lathuilière $\cdot$ E. P. Verrecchia \\ J. Geister
}

Received: 8 October 2006 / Accepted: 16 May 2007 / Published online: 26 June 2007

(C) Springer-Verlag 2007

\begin{abstract}
A morphometrical method to quantify and characterize coral corallites using Richardson Plots and Kaye's notion of fractal dimensions is presented. A Jurassic coral species (Aplosmilia spinosa) and five Recent coral species were compared using the Box-Counting Method. This method enables the characterization of their morphologies at calicular and septal levels by their fractal dimensions (structural and textural). Moreover, it is possible to determine differences between species of Montastraea and to tackle the high phenotypic plasticity of Montastraea апnиlaris. The use of fractal dimensions versus conventional
\end{abstract}

Communicated by Geology Editor B. Riegl.

B. Martin-Garin $(\square)$

Tethys Ocean, 15 impasse Ramel,

83320 Carqueiranne, France

e-mail: tethysocean@aol.com

B. Martin-Garin

Institut fuer Geologie der Universitaet Bern,

Baltzerstrasse 1, 3012 Bern, Switzerland

B. Lathuilière

G2R, Nancy-Université, CNRS, BP 239,

54506 Vandoeuvre-lès-Nancy, France

E. P. Verrecchia

Institut de Géologie de l'Université de Neuchâtel,

Rue Emile Argand 11, 2007 Neuchâtel, Switzerland

J. Geister

Abteilung Erdwissenschaften, Paläontologie, Naturhistorisches Museum, Bernastrasse 15,

3005 Bern, Switzerland

\section{J. Geister}

Institut fuer Geologie der Universitaet Bern,

Baltzerstrasse 1, 3012 Bern, Switzerland methods (e.g., measurements of linear dimensions with a calliper, landmarks, Fourier analyses) to explore a rugged boundary object is discussed. It appears that fractal methods have the potential to considerably simplify the morphometrical and statistical approaches, and be a valuable addition to methods based on Euclidian geometry.

Keywords Fractal $\cdot$ Corallite $\cdot$ Method $\cdot$ Morphology . Variability

\section{Introduction}

While the idea of "fractals" was rapidly taken up in various fields of physics (Mandelbrot 1983; Feder 1988; Kaye 1989, 1994; Gouyet 1992; Vicsek 1992), its use in describing biological forms has received less attention. Applications of fractals are used to distinguish malignant and benign tumor cells (Nonnenmacher et al. 1994; Losa et al. 1997, 2002), to study geometry of auditory nerve-spike trains (Teich and Lowen 1994), and the neural network (Jelinek and Fernandez 1998). Fractals have also been used in microbiology (Smith et al. 1989; Sedlák et al. 2002; Veselá et al. 2002), and to characterize biological objects like leaf shape (Morse et al. 1985; Vlcek and Cheung 1986; Prusinkiewicz 1993; Slice 1993; Mancuso 2001). However, the origins of fractal structures are difficult to understand. Their mathematical formulation and geometrical characteristics can be simplified for use as mathematical descriptors or as sources of simulation (Murray 1991; Wolfram 2002). For example, fractal growth allowed simulation of complex growth processes in corals, sponges, seaweeds (Kaandorp 1994; McEvoy and Kaandorp 1996; Kaandorp and Kübler 2001; Kaandorp and Sloot 2001; Merks et al. 2003), stromatolites (Verrecchia 1996) and plants (Prusinkiewicz et al. 1996). 
Analysis of fractal dimension also provides opportunities to treat large structures such as shallow-water coral communities (Bradbury and Reichelt 1983; Basillais 1997, 1998) or aerial and remote sensing images (Purkis et al. 2005, 2006). Patches of corals, algae or other organisms can be recognized by their own fractal dimensions allowing to delimit bottom communities, quantify coral cover, or to evaluate surfaces damaged by hurricanes.

Fractal geometry is complementary to Euclidian geometry. To measure a distance, a surface or a volume, a common method in fractal geometry involves covering sets with boxes in which the distance, the surface, or the volume are taken as units of measurement. To define the dimension of a structure, it is necessary for it to include boxes of every possible distance between two points. This requirement is always observed in nature (Gouyet 1992) and allows the fractal dimension of an object to be defined (Tricot 1982). Fractional dimension provides a measurement of roughness of fractal curves: lines have a dimension of one, surfaces a dimension of two, and solid bodies a dimension of three. As a rough curve wanders around on a plane, it may become so rough that it fills the plane on which it lies. Thus, increase in roughness is considered to be also an increase in dimension and the dimension of a fractal curve characterizes how the measured length between given points increases as scale decreases. While the topological dimension of a line and a surface are always one and two respectively, the fractal dimension of a rough line may be any real number between one and two, and, for a rough surface, any real number between two and three.

The study of scleractinian morphology and taxonomy evolved from description of purely topographic characteristics with casual quantification of corallite diameters (Michelin 1840-1848; d'Orbigny 1850) to systematic quantification of number of septa and calicular diameters (Koby 1880-1889). Microarchitecture was purely descriptively used by Alloiteau $(1952,1957)$ and later quantified (Gill 1967; Chevalier 1971; Gill and Lafuste 1971; Marchand-Stiévenart 1979). More recently, multivariate techniques such as factorial analysis of linear dimensions (Marchand-Stiévenart 1979; Lathuilière 1988, 1990, 2000a, b; Budd 1993; Budd et al. 1994; Bosellini and Stemann 1996; Pandey and Lathuilière 1997; Lathuilière and Gill 1998; Pandey et al. 1999; Maté 2003), image analysis for measurement of areas (Lathuilière and Budd 1994; Lathuilière 2000a, b) and methods based on landmarks (see Potts et al. 1993; Budd et al. 1994; Budd and Johnson 1996; Budd and Klaus 2001; Budd and Pandolfi 2004) were introduced.

Many morphological patterns found in nature such as corallite shape not only present a higher degree, but also a different level of complexity, which can cause difficulties in the quantification of these structures (Mandelbrot 1983). When Euclidian geometry reaches its limits, this study here proposes to use their fractal dimensions for quantification of corallite morphology at calicular and septal scales. The usefulness of this approach is demonstrated for six species of scleractinian corals, one fossil and five extant.

\section{Materials and methods}

Principal material

The Jurassic reef coral Aplosmilia spinosa displays high intraspecific and intracolonial variability, posing a challenge for conventional taxonomy and, therefore, an interesting test for this new technique. A. spinosa is a phaceloid colonial scleractinian, which occurred in the Tethys during the Upper Jurassic (Middle Oxfordian, Transversarium Zone, Martin-Garin et al. 2002; Martin-Garin 2005). Samples were taken from the northern Tethys Shelf of France (Lorraine, French Jura) and Switzerland (Swiss Jura). Specimens can be considered to belong to a coherent taxonomic unit of species rank despite the present unclear nomenclatural status of this and other nominal species of the genus Aplosmilia (Fig. 1). Forty-two corallites with an average diameter of $11.27 \pm 1.26 \mathrm{~mm}$ (mean $\pm \mathrm{SD}$ ) were processed from a total of 12 colonies.

\section{Additional material}

To compare results obtained from A. spinosa, individuals from five Recent coral species of the Caribbean Sea (Jamaica, Bahamas and Colombia) were added to the analyses. Two species are evolutionarily unrelated taxa and three others belong to the genus Montastraea. Six calices were taken from a single dome-shaped, phaceloid colony of Eusmilia fastigiata (Pallas) because of their apparent morphological similarity to the Jurassic Aplosmilia (Fig. 2a-c). Ten calices were sampled from a single massive colony of Dichocoenia stokesi (Milne Edwards and Haime), collected from San Andrés Island, Colombia (Fig. 2d-f). This species belongs to the same family of Meandrinidae as Eusmilia, but has a different colony structure. Corallites are evenly spaced and plocoid with septo-costae in two neatly alternating orders. The choice of specimens in a single colony of $D$. stokesi was guided by the wide intra-colony variability of the corallite shape (round to ovoid, Fig. 2d).

Twenty individual corallites from massive colonies of Montastraea were selected from published papers (Fig. $2 \mathrm{~g}$ k). Three corallites from one colony of Montastraea faveolata (Ellis and Solander), three corallites from one colony of Montastraea franksi (Gregory) and three corallites from a single colony of Montastraea annularis s.s. (Ellis and Solander) were taken from Budd and Klaus (2001) and originated from San Blas Island, Panama. Other corallites 
Fig. 1 Morphological characteristics of the Upper Jurassic reef coral Aplosmilia spinosa. a Top of a colony of A. spinosa (Euville, Lorraine, France).

b Detail of a corallite, sawed transversal section (Pagnysur-Meuse, France). The white arrow points to the drawings of the internal structures. c Detail of the internal structures of the corallite. (1) Internal sediment,

(2) lamellar columella, (3) a major septum after diagenesis. d Black and white Bitmap image of the skeleton/soft body (or skeleton/sediment) interfaces
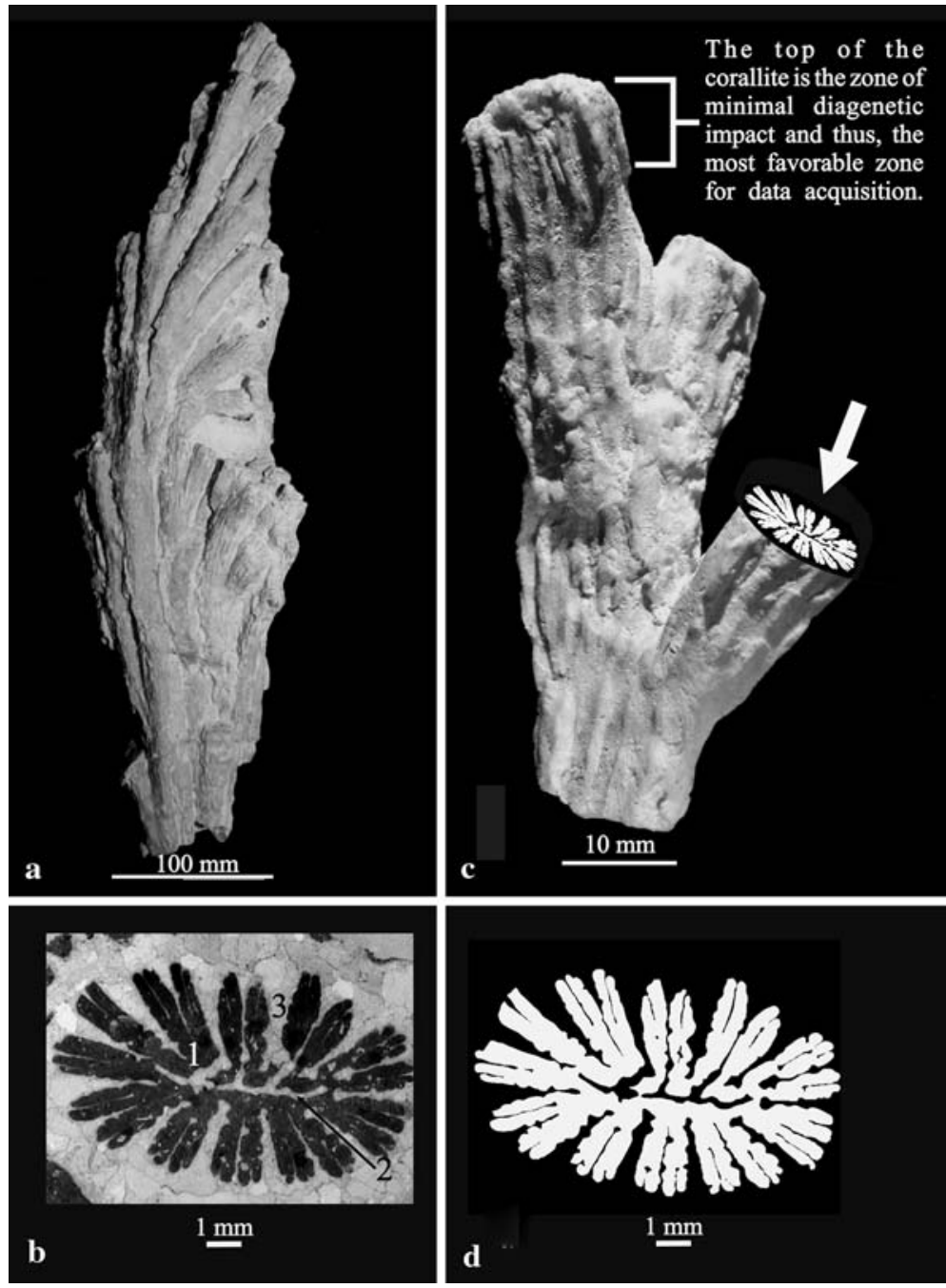

coming from eight colonies of Montastraea annularis s.l. were taken from Budd Foster (1979) and originated from a sand channel and the lagoon of Discovery Bay, Jamaica. Corallites of Montastraea are flush to conical with the colony surface. Septo-costae are neatly arranged with alternating short and long septa. Columellae are compact and small. Studied specimens of Jurassic and Recent species are deposited in the collection of the UMR CNRS 7566 G2R of the University Henri Poincaré-Nancy 1 (France).

Image data acquisition

After the death of a coral, the calices can be filled by a fine carbonate ooze thus moulding the calicular morphology. Calcite crystals frequently destroy the skeletal microarchitecture of Aplosmilia during diagenetic replacement of the original aragonite skeleton. Only the interface between soft body and skeleton of a polyp inside a calice may be molded by the micrite filling and may be preserved (Fig. 1b). Due to these preservation problems of the fossil material, it was impossible to study the ontogenesis of any individual calyx. Pictures could only be acquired across the last centimeter or so of the outer tip of each corallite (Fig. 1c).

After collection, transversal thin-sections were prepared from branches of Aplosmilia to obtain the outlines of calicular-sections. In recent colonies of both Eusmilia and Dichocoenia the empty calicular cavities were filled with epoxy resin under vacuum conditions before sectioning. Individual calices were photographed under a binocular microscope at $8 \times$ magnification with a CCD camera (Sony DXC-390P $\left.{ }^{\circledR}\right)$. Images of the Montastraea corallites were taken from the papers of Budd and Klaus (2001) and Budd Foster (1979). Corallite outline was highlighted and filled in black using the software Corel PHOTO-PAINT $10^{\circledR}$ and converted to a black and white bitmap (Fig. 1d).

Fractal analyses

This study used the Box-Couting Method, which involves laying a square mesh grid of various sizes $r$, over the image 
Fig. 2 Recent coral species. a Phaceloid colony of Eusmilia fastigiata. b Close-up view of a E. fastigiata corallite. c Cross-section of a $E$. fastigiata corallite. d Massive colony of Dichocoenia stokesi. e Close-up view of the plocoid corallites of $D$. stokesi. f Cross-section of $D$. stokesi corallite. g Massive colony of Montastraea annularis. $\mathbf{h}$ Detail of flush M. annularis corallites. i Close-up view of cross-section of $M$. annularis corallite (individual from the colony SUI 455551D, Fig. 8g, Budd Foster 1979). j Close-up view of Montastraea faveolata corallite (individual from colony SUI 95214 of Budd and Klaus 2001, Fig.5.3). k Close up view of Montastraea franksi corallite (individual from colony SUI 95228 of Budd and Klaus 2001, Fig. 5.1)

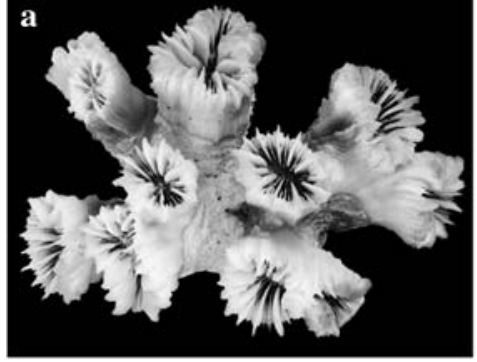

$10 \underline{\mathrm{mm}}$

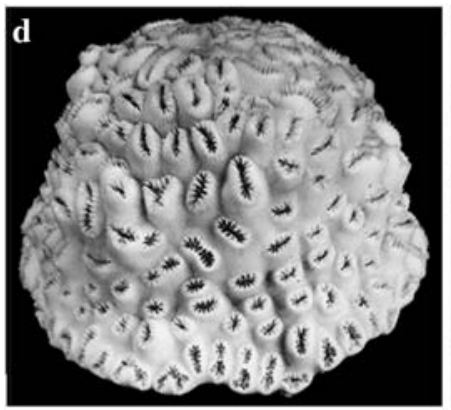

$10 \underline{\mathrm{mm}}$

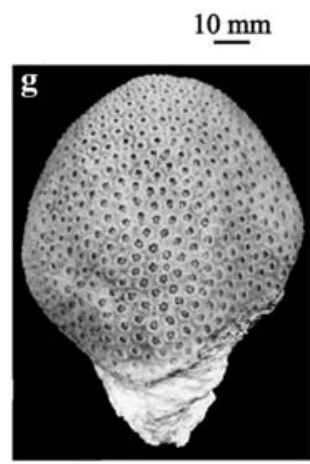

$10 \underline{\mathrm{mm}}$

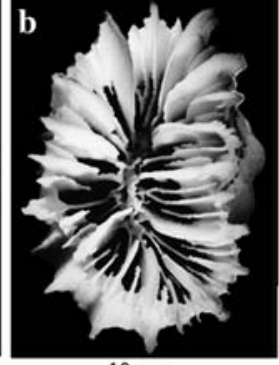

$\underline{10 \mathrm{~mm}}$

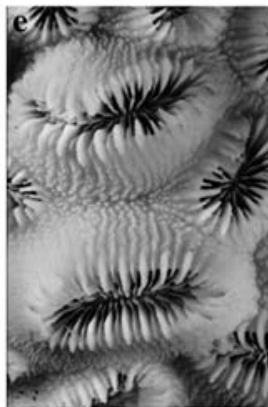

$10 \mathrm{~mm}$

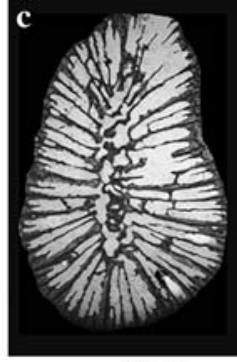

$\underline{10 \mathrm{~mm}}$

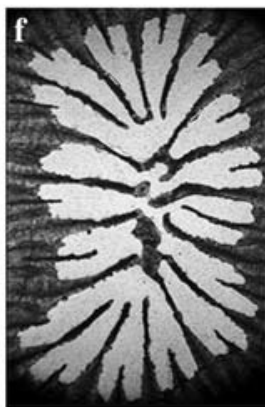

$5 \mathrm{~mm}$

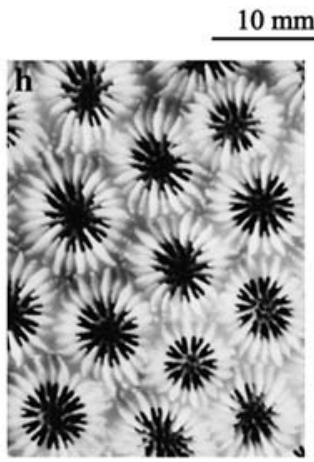

$1 \underline{\mathrm{mm}}$

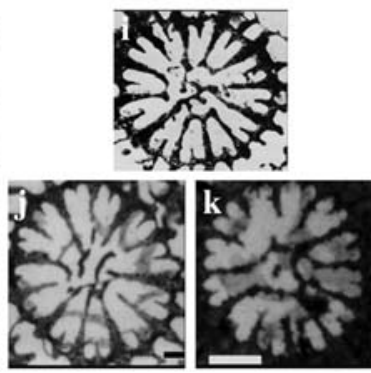

$1 \mathrm{~mm}$ object (fractal) to count how many boxes $N$, are needed to cover it completely (Fig. 3a-h). To implement the BoxCounting Method (Liebovitch and Toth 1989), the software HarFA (BCMet.exe for $\mathrm{PC}^{\circledR}$ ) was used (Zmeškal et al. 2001a; also downloadable on http://www.aplosmilia.free.fr/). The size of the square box forming the grid could vary from 100 to 2 pixels. The number $N$ of mesh boxes that contain any part of the fractal object were automatically counted by BCMet for each iteration with different box sizes: (1) $N_{\mathrm{B}}$ black squares completely filled by part of the object (Fig. 3i), (2) $N_{\text {BW }}$ black and white squares containing part of the object (Fig. 3i) and (3) $N \mathrm{w}$ white squares not filled by the object (Fig. 3i). Three fractal dimensions $\delta_{\mathrm{B}}, \delta_{\mathrm{W}}, \delta_{\mathrm{BW}}$ can be calculated by counting black $N_{\mathrm{B}}$, white $N_{\mathrm{W}}$ and partially black squares. $N_{\mathrm{BW}} . N_{\mathrm{B}}$ and $N_{\mathrm{W}}$ characterize fractal properties of the black and white plane, while $N_{\mathrm{BW}}$ characterizes properties of the black and white border (Zmeškal et al. 2001b). $\delta_{\mathrm{W}}$ and $\delta_{\mathrm{B}}$ are only meaningful for Euclidean objects such as a line, circle, square, etc. (Zmeškal et al. 2001b) whereas $\delta_{\mathrm{BW}}$ is meaningful for objects with a jagged, rough outline such as the corallites of Aplosmilia, Eusmilia, Dichocoenia and Montastraea.

For each specimen, four columns were created in STATVIEW $^{\circledR}$. Two of them, AX and AY contained the logarithm of the box size $(\log r)$ and the number of black and white boxes needed to cover the object $\left(\log N_{\mathrm{BW}}\right)$. The others, BX and BY were left blank. A bivariate plot at the log-log scale, known as Richardson Plot was created with $\log r$ on the $x$ axis versus $\log N_{\mathrm{BW}}$ on the $y$-axis (Fig. 4a). The logarithmical function thus obtained showed an apparent inflexion point (Fig. 4a). Using two slopes rather than one is proposed by Kaye $(1989,1994)$ in his definition of "discovering texture fractal". The initial theoretical consideration of Kaye was that the fine details and the data generated by a structure walk exploration of a rugged object yielded a fractal slope and a Euclidian slope (value equal to 1). He concluded that the second dataline of slope was in fact different from the value 1 , and corresponded to an exploration of the texture of the objects distinct from its structure. In order to find this inflexion point, the last data of the columns $\mathrm{A} X-\mathrm{A} Y$ were 
Fig. 3 Principle of the Box-Counting Method. a-h. The laying of square meshes of various sizes $r$ over the 1 bit image of a scleractinian corallite. I. The counting of the number of $N$ mesh boxes that contain any part of the object for all the mesh box sizes: $N_{\mathrm{B}}$ black squares (black arrow) that are completely filled up by the fractal object. $N_{\mathrm{BW}}$ black and white squares that contain only part of the object (white arrow). In this example of Aplosmilia spinosa, 10 black squares and 219 black and white squares are counted for a mesh box size of 20 pixels

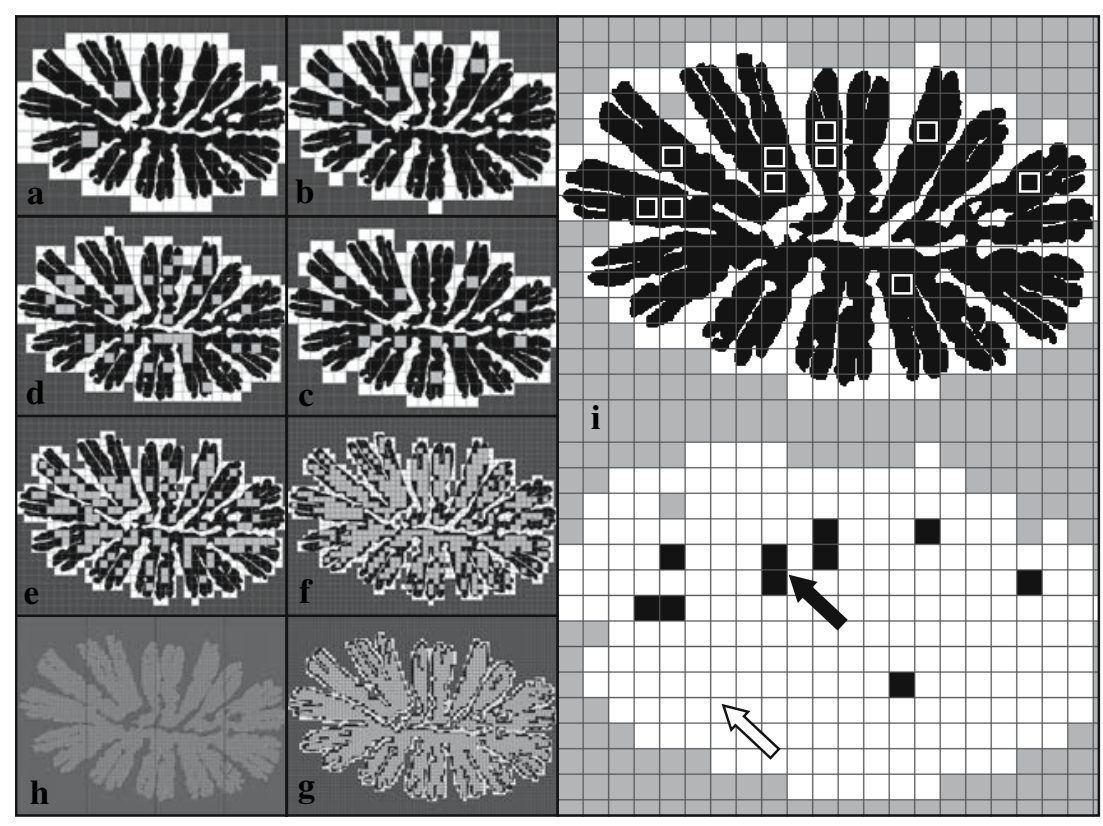

transferred in parallel to the columns $\mathrm{B} X-\mathrm{B} Y$, and placed in a new bivariate plot. Functions newly obtained from the data of both sets of columns (A and B) yielded two slopes identified by an equation $(\log N(r)=\delta(\log (1 / r))+\log k)$ and a coefficient of determination ( $r$-squared) as shown in Fig. 4b-c. The coefficient of determination ( $r$-squared) must be maximal for both slopes. It was necessary therefore to determine if any point surrounding the inflexion point belonged either to column A or to column B. The slope coefficients of both least square regressions were identified as the fractal dimensions. Fractal dimension, which is characteristic of the morphology, i.e., the overall structure of the corallite (calicular level), is defined as the structural fractal dimension $(\delta s)$. The fractal dimension, which is useful for the description of the texture or fine details at the septal level is defined as the textural fractal dimension $\delta t$ (Kaye 1978, 1986, 1989, 1994; Kaye et al. 1994; Fig. 4b-c).

\section{Results}

General results

Using just two parameters in the coral morphometrics yields significant results. Individual calices from the same species clustered into a given structural fractal dimension $(\delta s)$ (Fig. 5a). In the plot, two sets were clearly identified. On one hand, morphologies with greater calicular and septal complexities (jagged outlines) displayed higher $\delta s$ and $\delta t, \delta s 1.67 \pm 0.02$ (mean $\pm \mathrm{SD}$ ) and $\delta t 1.00 \pm 0.03$, respectively, for A. spinosa (Fig. 5b) and $\delta s$ 1.73-1.74, $\delta t 0.99-$ 1.00 for E. fastigiata (Fig. 5a). Despite their close similarity, both species may be clearly separated from each other.
M. faveolata showed less ruggedness of the corallite ( $\delta s$ $1.15 \pm 0.01 ; \delta t 0.805 \pm 0.065)$, as did D. stokesi $(\delta s$ $1.24 \pm 0.02 ; \delta t 0.78 \pm 0.05), M$. annularis $(\delta s 1.265 \pm$ $0.025 ; \delta t 0.805 \pm 0.025)$, and $M$. franksi ( $\delta s 1.30 ; \delta t$ $0.835 \pm 0.065)$. The general shape of the A. spinosa corallite was less rough (jagged) than that of E. fastigiata. Nevertheless, the broader variability of septal morphology in A. spinosa was clearly visible and could be explained by the small number of samples of E. fastigiata calices studied. Analyzing intracolonial variability in A. spinosa demonstrates that most of intraspecific variability is generated by calicular differences within a colony.

\section{Discussion}

Analysis of fractal dimension was demonstrated here to provide an accurate and objective mathematical descriptor that allows complex morphologies to be described in biology and paleontology with simple parameters. Fractals provide a straightforward method to quantify all the details of the morphology of coral structure from the scale of a colony to that of microarchitecture. The use of fractals provides a powerful tool to describe natural objects and can be combined with other methods of investigation, but it should be taken into consideration that fractal dimensions are generated in a non-Euclidian space. Results given by the fractal dimensions imply that the degrees of the calicular $(\delta s)$ and septal $(\delta t)$ irregularities and/or fragmentation are identical in any given cluster provided by the analysis. Specimens only cluster according to the ruggedness of the jagged outline. Individuals with a high structural fractal dimension $(\delta s)$, show a lower variability regarding the textural fractal 

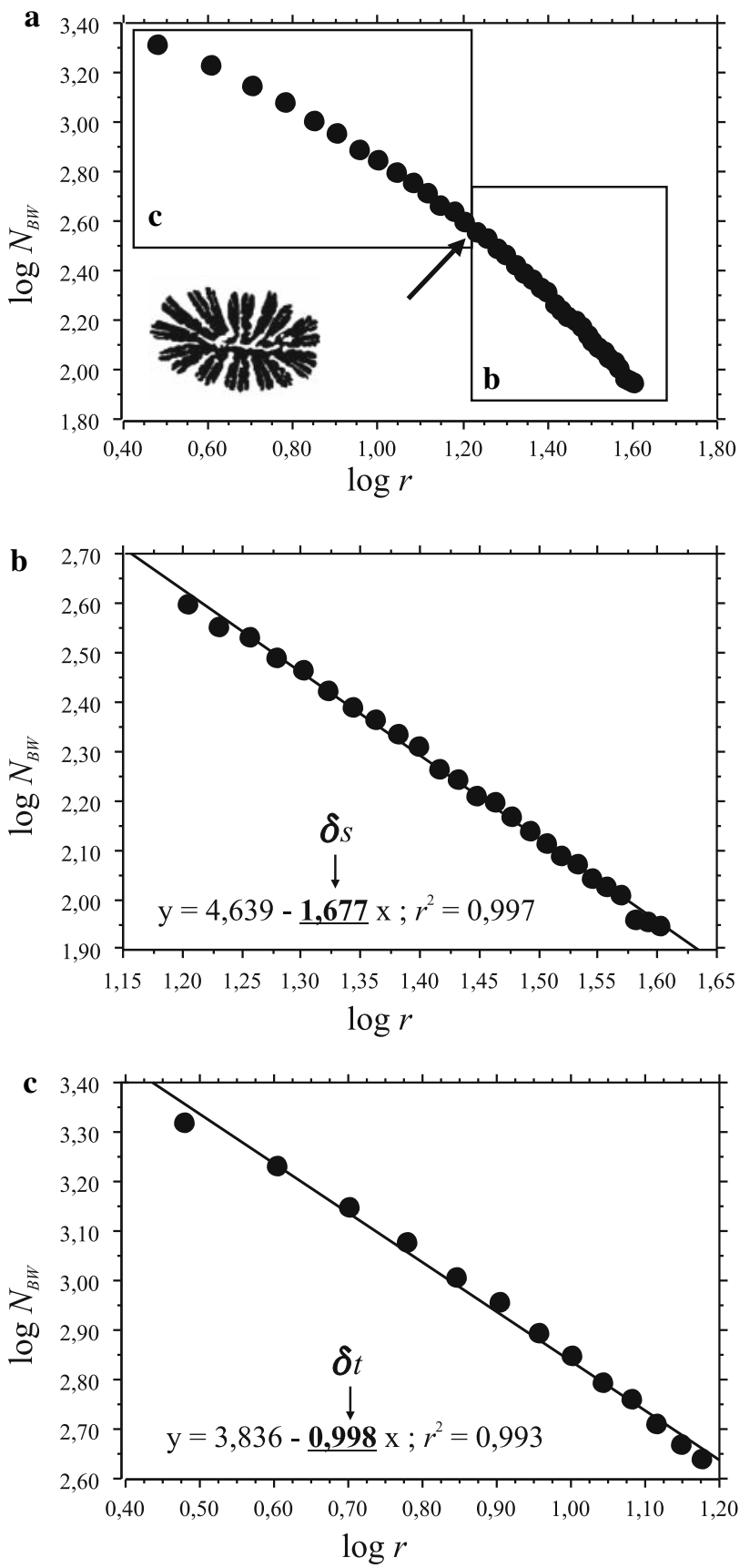

Fig. 4 a Plotting on a log-log coordinate system the box size (log $r$ on $x$-axis) versus the number of black and white boxes needed to cover the object ( $\log N_{\mathrm{BW}}$ on $y$-axis) entirely, (Richardson Plot). The black arrow indicates the inflexion point given by the maximal coefficients of determination $r$-squared of the two least square regressions. b The slope coefficient of the first regression yields the structural fractal dimension of the corallite $\delta s$ and corresponds to its overall morphology. c The second regression yields the textural fractal dimension $\delta t$, which describes the texture or fine details at the septal level

dimension $(\delta t)$, than those individuals with a low structural fractal dimension $(\delta s)$.

Despite obvious limitations imposed by the small sample size of Montastraea in these analyses, the distinction of closely related species as named in the literature is reproduced by the fractal approach. M. annularis showed the largest $\delta s \quad$ standard deviation $\quad(\delta s=1.265 \pm 0.025$; mean $\pm \mathrm{SD}$ ). This may have been due to sample size constraints, but the effect of transplantation made by Budd Foster (1979) of colonies of $M$. annularis into different environments of the Discovery Bay reef complex in Jamaica (patch reef, lagoon, reef and sand channel) cannot be excluded. Due to the subsequent discovery of sibling species (van Veghel and Bak 1993; Knowlton et al. 1992) in the species group, the specific attribution to the restricted group M. annularis s.s. is also questionable.

The basis for the analyses of this study was the morphology of the surface between the living body and the skeleton of the coral (polyp/skeleton interface). This interface is the keystone of shape in corals since linear dimensions of skeletal volumes (e.g., thickness of thecal walls or septa) indirectly reflect carbonate productivity rather than shape (Lathuilière and Budd 1994). Fractal analysis allows measurement of the most sensitive specific indicator surface and may therefore prove to be a powerful tool for taxonomy.

Fractal geometry versus conventional methods

When compared to conventional linear measurements or geometric morphometrics, the use of fractal dimension provides advantages and few shortcomings that make it useful to quantify and to characterize biological or paleontological shapes.

The first quantitative parameters used for statistical comparisons were linear series of linear dimensions, measured directly from the organism (Fig. 6a). Linear measurements have serious drawbacks, because they do not record the entire shape, but only describe select dimensions of a few objects chosen by an observer. If the thickness of a septum is measured because it is recognized as a well-known entity, supposed to be homologous to other septa, new questions arise concerning the localization of borders between skeletal entities (i.e., between septa and wall, septa and dissepiment, columella and septa, etc.) and the homology of the structures. Also, when choosing to localize the measurement, excluding most other localized information and their relation to the complete outline is inevitable. Fractals, on the other hand, operate at several different levels of observation, taking into account the entire shape of the corallite outline. The progressive reduction of box-size in the Box-Counting Method quantifies the overall shape of the corallite (Fig. 4b) and then records the fine details at the septal level (Fig. 4c). Fractals do not quantify a septum as a homologous structure, but quantify its ruggedness from the scale of the entire septum down to the scale of a septal granule. 
Fig. 5 Plot of the results: structural fractal dimension $\delta s$ (on $x$-axis) versus textural fractal dimension (on $y$-axis).

a Individuals from the same species are grouped for a given structural fractal dimension $(\delta s)$. Two clusters are identifiable: (1) Eusmilia and Aplosmilia, which display the most complex corallite morphology.

(2) Dichocoenia and the three species of Montastraea. In Montastraea annularis, and Montastraea franksi the septal morphology is closer to each other, whereas $M$. annularis has a greater $\delta s$ variability. b Detail of the plot of Aplosmilia spinosa to show the intraspecific and intracolonial variability (circled crosses, solid circles, and squares correspond to individuals from the same colonies)
Aplosmilia spinosa $(\mathrm{N}=42)$

Dichocoenia stokesi $(\mathrm{N}=10)$

Eusmilia fastigiata $(\mathrm{N}=6)$

Montastraea annularis ( $\mathrm{N}=15)$

Montastraea faveolata $(\mathrm{N}=3)$

Montastraea franksi $(\mathrm{N}=3)$
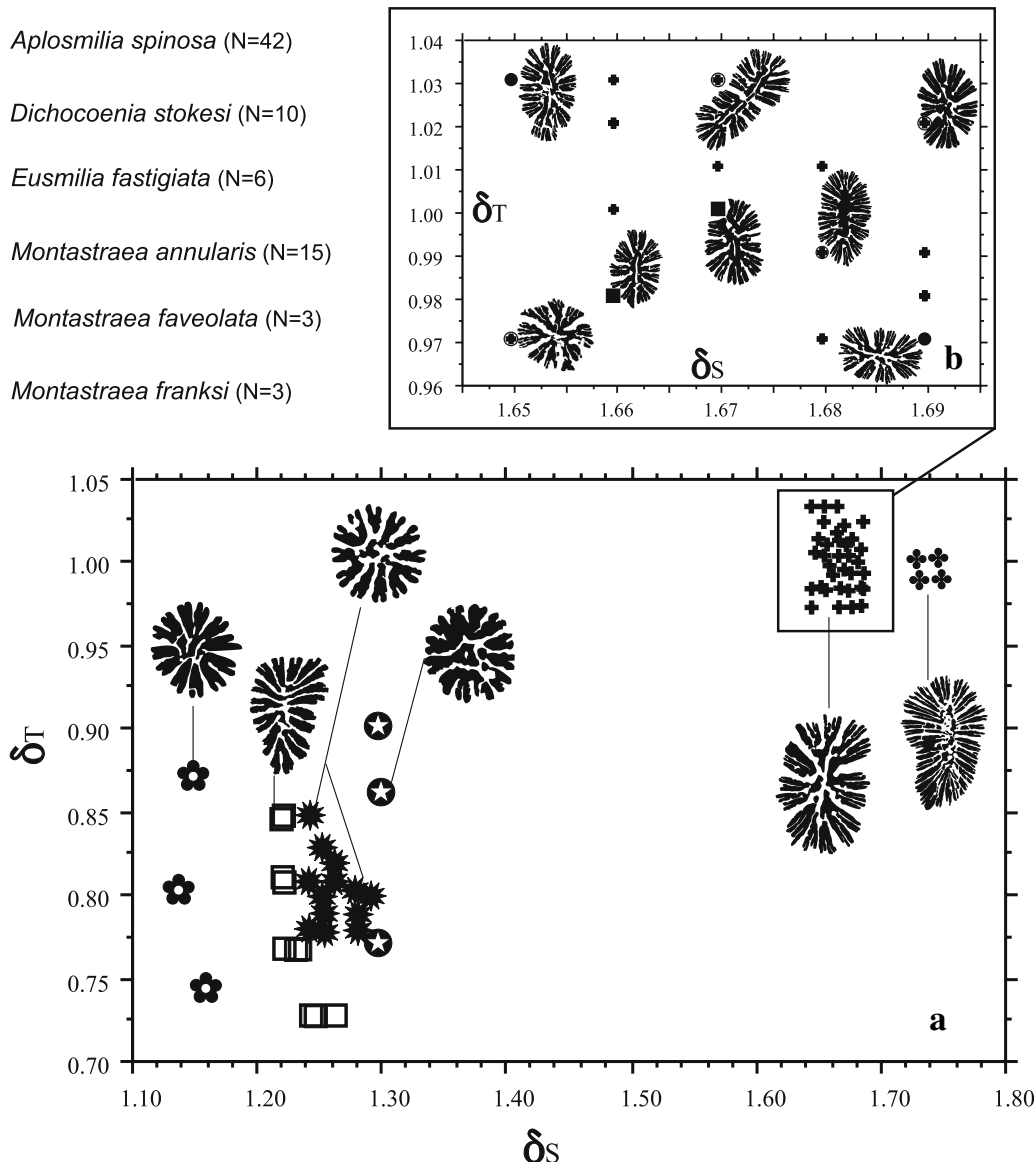

Various versions of Fourier shape analysis are also applicable to record the shape of an outline in its entirety. The principle is to fit the observed outline to a theoretical graph of a complex sinusoidal function that can be decomposed into numerous simple functions. The parameters of the fitted function are then used in multivariate analyses as descriptors of the outline (Rohlf 1990; Verrecchia et al. 1996; Moussa 1999). However, for the complex outline of a corallite, this method has major drawbacks. Firstly, while only a few parameters are necessary to reconstruct a simple outline (for example that of a sea urchin test) many more are needed for the considerably more complex outline of a corallite. More than 60 parameters (representing the 60 amplitudes of harmonics) were needed to reconstruct the outline of an A. spinosa corallite at $89.2 \%$ of the cumulative variance (called power of the harmonics in Fourier transforms), by successive increments of the harmonics (Fig. 6b). Only 6-12 harmonics were needed to reconstruct the perfect outline of a sea urchin test (Fig. 6b). To obtain solid results with Fourier transforms, the outline of the object must be completely closed, which was not the case for most of the specimens of this study (Fig. 6b). Fractal dimension analyses are easier to apply and understand by using only two parameters, the structural $(\delta s)$ and the tex- tural $(\delta t)$ fractal dimensions (Kaye 1989, 1994), which entirely characterize the outline of the corallites.

Much work in geometric morphometrics of corals has focused on the analysis of landmark data (Budd and Klaus 2001; Budd and Pandolfi 2004). The most valuable landmarks are anatomical points that should be traceable along the ontogeny. For corals, due to the variable expression of the bilateral symmetry, such a requirement is not clearly established and it is difficult to localize homologous points as easily as it can be done, for example, in a mosquito wing (Rohlf and Slice 1990). Recognizing homologies, especially of the landmark type 1 as defined by Bookstein (1991) or Marcus et al. (1996), is usually not possible (Fig. 6c). Fractal analyses thus offer the possibility of avoiding the problems with landmarks that are inherent in the orientation of samples, in symmetry or homologies between structures. By contrast, methods based on homologies such as cladistics cannot use the fractal morphometric method discussed here.

It cannot be excluded that similar fractal dimensions may correspond to radically different shapes and for this reason more naturalistic and other morphometric approaches should not be discarded. If both fractal dimensions are not sufficient to separate different forms, further 
Limit of measurements of the linear dimension using a calliper

a
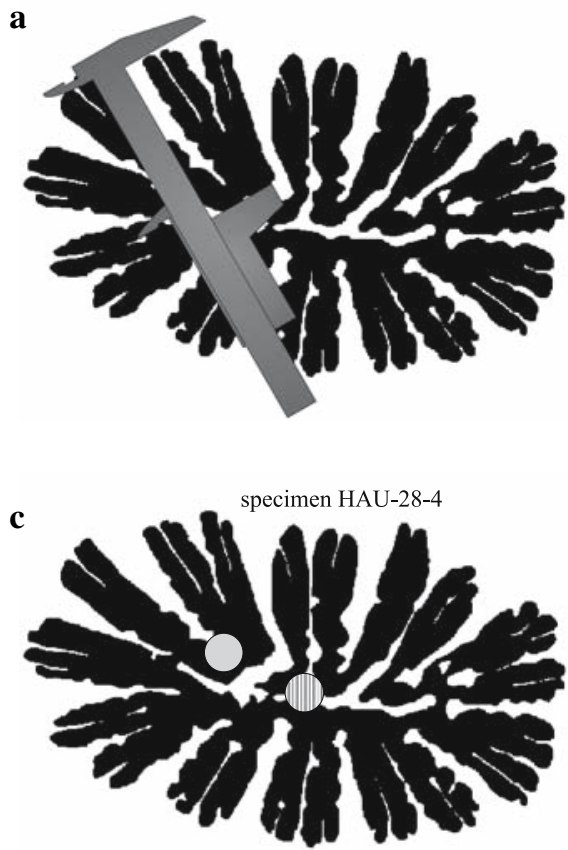

The outline is not completely closed so that part of the corallite is not taken in consideration in the Fourier analyses

b
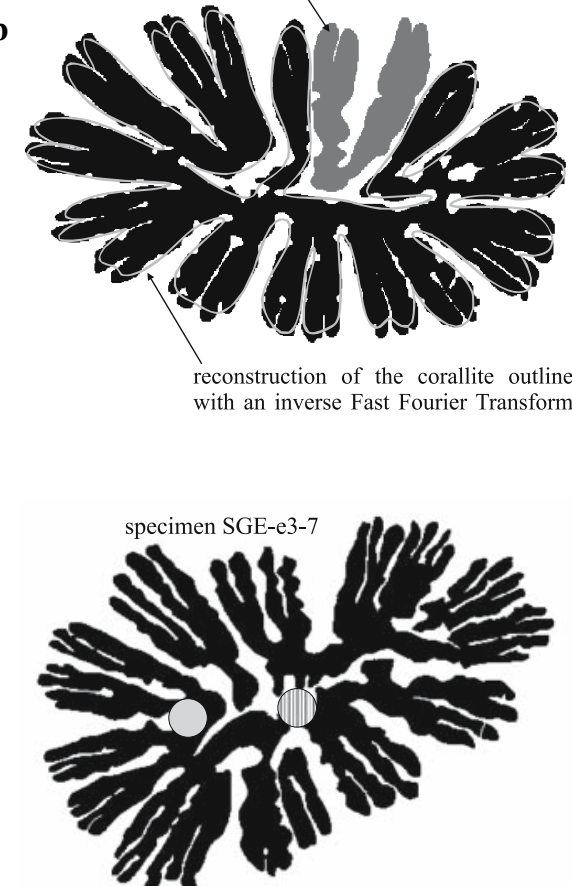

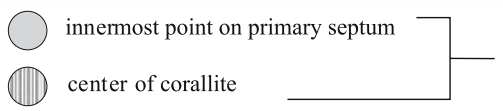

Fig. 6 Unsuitable methods of Euclidian geometry to quantify the corallite variability of a species. a The first quantitative parameters used for statistical comparisons were linear series of linear dimensions, directly measured with a calliper on the skeleton. Linear dimensions have major drawbacks because they do not permit to study the whole shape, but only to describe a few local dimensions. b Using 512 points to sample an Aplosmilia spinosa outline, the successive increment of

discrimination is possible by including additional linear or geometrical characters into the statistical analyses.

Perspective of this new method in coral research

Advantages of fractal dimension analyses are obvious in morphometrics of most marine sessile organisms living within the reefs, such as corals (e.g., scleractinians, octocorals, hydrozoans), seaweeds, algae, sponges, bryozoans, bacterians, and even gastropod color patterns such as Conus shells. Consequently, the method can be used for many applications of morphometrics, i.e., systematics, evolution, biogeography, biostratigraphy, ecology, functional morphologic analyses whenever these disciplines require good distinctions of shapes. One fundamental question in biology is how the physical environments interplay with the genome to control the morphogenesis. Using fractal dimensions to characterize the shape and quantify the phenotypic plasticity of such organisms in their different environments can be combined with other algorithmic methods (e.g.,
For example, these two points are not landmarks. There is no homology between the two specimens because of the radial symmetry of scleractinians. There is no homology in terms of ontogenesis as defined by Bookstein (1991) or Marcus et al (1996)
60 harmonics (60 parameters to be introduced into the statistical analyses) of a Complex Discret Fourier Transform reconstructs the object outline at $89.2 \%$. Scleractinian corallites have no completely closed outline as would require a Fourier analysis. $\mathbf{c}$ There is no homology to define landmarks (as Bookstein 1991; Marcus et al. 1996) on a scleractinian corallite

Laplacian Model of Branching Growth, Cellular Automata, Diffusion-Limited Aggregation) to understand their growth (see Verrecchia 1996; Kaandorp and Kübler 2001).

In conclusion, fractal dimensions have much to offer to coral morphometrics. (1) Outlines and fine morphological structures of coral corallites are entirely analyzed and quantified at different levels of observation (calicular and septal). The first applications suggest that they provide results adequate for delimitation of coral taxa. (2) The Box-Counting Method is straightforward to apply and easily reproducible for Recent and fossil scleractinian corallites. (3) Statistical analyses are simplified, because only two parameters are necessary to characterize coral corallites: the structural fractal dimension $(\delta s)$ and the textural fractal dimension $(\delta t)$.

Acknowledgments We are greatly indebted to the staff of thin-section preparation: Vlado Grečo from the Institute of Geology at Berne, and to Michel Lemoine of the Muséum National d'Histoires Naturelles at Paris for impregnation of Recent coral skeletons with artificial resin Finally, we are grateful to Martin Engi (Berne), for reviewing our 
French-German English, and to our reviewers for their constructive remarks. This research was funded by the Swiss National Science Foundation (grant 21-61834.00).

\section{References}

Alloiteau J (1952) Embranchement des coelentérés. In: Piveteau J (ed) Traité de Paléontologie. Masson, Paris, pp 376-684

Alloiteau J (1957) Contribution à la systématique des madréporaires fossiles. C.N.R.S. éds, Paris

Basillais E (1997) Coral surfaces and fractal dimensions: a new method. Compt Rendus Acad Sci III Sci Vie 320:653-657

Basillais E (1998) Functional role of the fractal morphology of corals: a full model of the nutrient turbulent diffusion fluxes to a coral reef. Compt Rendus Acad Sci III Sci Vie 321:295-298

Bookstein FL (1991) Morphometric tools for landmark data geometry and biology. Cambridge University Press, Cambridge

Bosellini FR, Stemann TA (1996) Autecological significance of growth form in the scleractinian Actinacis rollei Reuss (Oligocene, Lessini Mountains, Northern Italy). Boll Soc Paleontol Ital Vol Sp 3:31-43

Bradbury RH, Reichelt RE (1983) Fractal dimension of a coral reef at ecological scales. Mar Ecol Prog Ser 10:169-171

Budd FA (1979) Phenotypic plasticity in the reef corals Montastraea annularis (Ellis \& Solander) and Siderastrea siderea (Ellis \& Solander). J Exp Mar Biol Ecol 39:25-54

Budd AF (1993) Variation within and among morphospecies of Montastraea. Cour Forsch Inst Senckenberg 164:241-254

Budd AF, Johnson KG (1996) Recognizing species of late Cenozoic Scleractinia and their evolutionary patterns. Paleontol Soc Pap 1:59-79

Budd AF, Klaus JS (2001) The origin and early evolution of the Montastraea "annularis" species complex (Anthozoa: Scleractinia). J Paleontol 75:527-545

Budd AF, Pandolfi JM (2004) Overlapping species boundaries and hybridization within the Montastraea "annularis" reef coral complex in the Pleistocene of the Bahama Islands. Paleobiology 30:396-425

Budd AF, Johnson KG, Potts DC (1994) Recognizing morphospecies in colonial reef corals: I- Landmark-based methods. Paleobiology 20:484-505

Chevalier JP (1971) Les scléractiniaires de la Mélanésie française. Expédition française sur les récifs coralliens de la Nouvelle-Calédonie. Editions de la Fondation Singer-Polignac, Paris

Feder J (1988) Fractals. Plenum Press, New York

Gill GA (1967) Madréporaires. II. Quelques précisions sur les septes perforés des polypiers mésozoïques. Mem Soc Geol Fr 106:58-81

Gill GA, Lafuste JG (1971) Madréporaires simples du Dogger d'Afghanistan: étude sur les structures de type Montlivaltia. Mem Soc Geol Fr NS 115:1-40

Gouyet JF (1992) Physique et structures fractales, Paris

Jelinek HF, Fernandez E (1998) Neurons and fractals: how reliable and useful are calculations of fractal dimensions? J Neurosci Methods 81:9-18

Kaandorp JA (1994) Fractal modelling growth and form in biology. Springer, Heidelberg

Kaandorp JA, Kübler JE (2001) The algorithmic beauty of seeweeds, sponges, and corals. Springer, Heidelberg

Kaandorp JA, Sloot PMA (2001) Morphological models of radiate accretive growth and the influence of hydrodynamics. J Theor Biol 209:257-274

Kaye BH (1978) Specification of the ruggedness and/or texture of a fine particle profile by its fractal dimension. Powder Tech 21:116
Kaye BH (1986) The description of two-dimensional rugged boundaries in fine particle science by means of fractal dimensions. Powder Tech 46:245-254

Kaye BH (1989) A random walk through fractal dimensions, 1st edn. VCH Publisher, Weinheim

Kaye BH (1994) A random walk through fractal dimensions, 2nd edn. Wiley, Chichester

Kaye BH, Clark GG, Kydar Y (1994) Strategies for evaluating boundary fractal dimensions by computer aided image analysis. Part Part Syst Char 11:411-418

Knowlton N, Weil LA, Guzman HM (1992) Sibling species in Montastrea annularis, coral bleaching, and the coral climate record. Science 255:330-333

Koby F (1880-1889) Monographie des polypiers jurassiques de la Suisse. Mémoires de la Société Paléontologique Suisse 7-16:1-582

Lathuilière B (1988) Analyse de populations d'isastrées bajociennes (scléractiniaires jurassiques de France). Conséquences taxonomiques stratigraphiques et paléoécologiques. Geobios (Paris) 21:269-305

Lathuilière B (1990) Periseris, scléractiniaire colonial jurassique. Révision structurale et taxinomie de populations bajociennes de l'est de la France. Geobios (Paris) 23:33-55

Lathuilière B (2000a) Coraux constructeurs du Bajocien inférieur de France, $1^{\text {ère }}$ partie. Geobios (Paris) 33:51-72

Lathuilière B (2000b) Coraux constructeurs du Bajocien inférieur de France, $2^{\text {ème }}$ partie. Geobios (Paris) 33:153-181

Lathuilière B, Budd AF (1994) Analyse d'image et analyse morphofonctionnelle des coraux. Compt Rendus Acad Sci IIA Sci Ter Plan 318:1273-1276

Lathuilière B, Gill GA (1998) Dendraraea corail scléractiniaire branchu jurassique: structure systématique, écologie. Palaeontogr Abt A Palaeozool-Stratigr 248:145-162

Liebovitch LS, Toth T (1989) A fast algorithm to determine fractal dimensions by box-counting. Phys Lett 141:386-390

Losa GA, Nonnenmacher TF, Merlini D, Weibel ER (eds) (1997) Fractals in biology and medicine, vol II. Birkhaeuser, Basel

Losa GA, Merlini D, Nonnenmacher TF, Weibel ER (eds) (2002) Fractals in biology and medicine, vol III. Birkhaeuser, Basel

Mancuso S (2001) The fractal dimension of grapevine leaves as a tool for ampelographic research. HarFA-Harmonic and Fractal Image Analysis 6-8

Mandelbrot BB (1983) The fractal geometry of nature. Freeman, W.H., New York

Marchand-Stiévenart J (1979) Etude de la variabilité du squelette chez les madrépores. Ph.D. thesis Université de Liège, p 264

Marcus LF, Corti M, Loy A, Naylor GJP, Slice DE (eds.) (1996) Advances in morphometrics. NATO ASI series, Plenum Press, New York

Martin-Garin B (2005) Climatic control of Oxfordian coral reef distribution in the Tethys Ocean. Including a comparative survey of recent coral communities (Indian Ocean) and a new method of coral morphometrics based on fractal dimensions. Ph.D. thesis Universität Bern, p 253

Martin-Garin B, Lathuilière B, Geister J (2002) Récifs, coraux et climats oxfordiens de la Téthys. Doc Lab Geol Facul Sci Lyon 156:154-155

Maté JL (2003) Ecological, genetic, and morphological differences among three Pavona (Cnidaria: Anthozoa) species from the Pacific coast of Panama. I. P. varians, $P$. chiriqiensis, and $P$. frondifera. Mar Biol 142:427-440

McEvoy H, Kaandorp JA (1996) On modeling environmentally-sensitive growth forms and cellular automata using multiset transformation. Fractals 4:509-520

Merks R, Hoekstra A, Kaandorp J, Sloot P (2003) Models of coral growth: spontaneous branching, compactification and the Laplacian growth assumption. J Theor Biol 224:153-166 
Michelin H (1840-1848) Iconographie zoophytologique. Description par localités et terrains des polypiers fossiles de France. Bertrand Editions, Paris

Morse DR, Lawton JH, Dodson MM, Williamson MH (1985) Fractal dimension of vegetation and the distribution of arthropod body lengths. Nature 314:731-733

Moussa B (1999) Biometrics analysis of variation in spatangoid echinoid Linthia from the Maastrichtian and Paleocene of the Lullemmeden Basin, Niger, West Africa. In: Daniela M, Candia C, Bonasero F (eds) Echinoderm Research 1998, Rotterdam, pp 341-346

Murray JD (1991) Mathematical biology. Springer, Heidelberg

Nonnenmacher TF, Losa GA, Weibel ER (eds) (1994) Fractals in biology and medicine, vol I. Birkhaeuser, Basel

d'Orbigny A (1850) Prodrome de paléontologie stratigraphique universelle des animaux mollusques et rayonnés. Masson, Paris

Pandey DK, Lathuilière B (1997) Variability in Epistreptophyllum from the Middle Jurassic of Kachchh, Western India: an open question for the taxonomy of Mesozoic scleractinian corals. J Paleontol 71:564-577

Pandey DK, McRoberts CA, Pandit MK (1999) Dimorpharaea (Scleractinia, Anthozoa) from the Middle Jurassic of Kachchh, India. J Paleontol 73:1015-1028

Potts DC, Budd AF, Garthwaite RL (1993) Soft tissue vs. skeletal approaches to species recognition and phylogeny reconstruction in corals. Cour Forsch Inst Senckenberg 164:221-229

Prusinkiewicz P (1993) Modeling and visualization of biological structures. In: Proceeding of Graphics Interface, pp 128-137

Prusinkiewicz P, Hammel M, Hanan J, Mech R (1996) Visual models of plant development. In: Rozenberg G, Salomaa A (eds) Handbook of formal languages. Springer, Berlin, pp 1-67

Purkis SJ, Riegl BM, Andréfouët S (2005) Remote sensing of geomorphology and facies patterns on a modern carbonate ramp (Arabian Gulf, Dubai, U.A.E.). J Sediment Res 75:861-876

Purkis SJ, Riegl BM, Dodge RE (2006) Fractal patterns of coral communities: evidence from remote sensing. In: Proc 10th Int Coral Reef Symp, pp 1753-1762

Rohlf FJ (1990) Fitting curves to outlines. In: Rohlf FJ, Bookstein FL (eds) 2nd Michigan morphometrics workshop. Museum of Zoology, University of Michigan, pp 167-177
Rohlf FJ, Slice D (1990) Extensions of the Procrustes method for the optimal superimposition of landmarks. Syst Zool 39:40-59

Sedlák O, Zmeškal O, Komendová B, Dzik P (2002) HarFA—The use of fractal analysis for the determination of cell diameter-model calculation. HarFA - Harmonic and Fractal Image Analysis 1920

Slice D (1993) The fractal analysis of shape. In: Marcus LF, Bello E, Garciá-Valdecasas A (eds) Contributions to morphometrics. Mus Nac Cienc Nat, Madrid, pp 166-190

Smith Jr TG, Marks WB, Lang GD, Sheriff Jr WH, Neal EA (1989) A fractal analysis of cell images. J Neurosci Methods 27:173-180

Teich MC, Lowen SB (1994) Fractal patterns in auditory nerve-spike trains. IEEE Eng Med Biol Mag 13:197-202

Tricot C (1982) Two definitions of fractional dimension. Math Proc Camb Phil Soc 91:57-74

van Veghel MLJ, Bak RPM (1993) Intraspecific variation of a dominant Caribbean reef building coral. Montastrea annularis: genetic, behavioral and morphometric aspects. Mar Ecol Prog Ser 92:255265

Verrecchia EP (1996) Morphometry of microstromatolites in calcrete laminar crusts and a fractal model of their growth. Math Geol 28:87-109

Verrecchia EP, Van Grootel G, Guillemet G (1996) Classification of Chitinozoa (llandoverian, Canada) using image analysis. Microsc Microanal Microstruct 7:461-466

Veselá M, Zmeškal O, Veselý M, Nežádal M (2002) The use of fractal analysis for the determination of yeast cell diameter. HarFAHarmonic and Fractal Image Analysis:21-22

Vicsek T (1992) Fractal growth phenomena, 2nd edn. World Scientific, Budapest

Vlcek J, Cheung E (1986) Fractal analysis of leaf shapes. Can J For Res $16: 124-127$

Wolfram S (2002) A new kind of science. Wolfram Media, Incorporation, Champaign

Zmeškal O, Nežádal M, Buchnícek M, Bzatek T (2001a) HarFAHarmonic and Fractal Image Analyser, software. http://www.fch. vutbr.cz/lectures/imagesci/. University of Technology, Brno

Zmeškal O, Veselý M, Nežádal M, Buchnícek M (2001b) Fractal analysis of image structures. HarFA-Harmonic and Fractal Image Analysis 3-5 